\title{
Trans boundary water issues between Kazakhstan and China
}

\author{
Assem Mustafina \\ College of Public Administration, Zhejiang University, P.R. China
}

\begin{abstract}
This paper discusses about trans boundary water issues between China and Kazakhstan, achievements and failures of Kazakhstan in addressing the problem to China, reasons of cross-border rivers problem, and negative consequences of unresolved problems in Kazakhstan (East Kazakhstan particularly). Investigation will be on why until now there is no agreement of proper usage of Trans Boundary Rivers. The paper also tackles about some approximate solutions to this problem and future perspectives between two countries on the question of Trans Boundary Rivers.
\end{abstract}

Keywords: China- Kazakhstan relations, Trans boundary waters, SCO, Shanghai Cooperation Organization

\section{Introduction}

The question of management of Tran's boundary water resources is a very sensitive issue, where Kazakhstan and China has not yet reached a consensus. China's policy in this area is becoming a cause of numerous discussions. It worries not only environmentalists and politicians, but ordinary people of Kazakhstan as well.

More than 20 rivers of Kazakhstan originate from the territory of China; the largest of which are Irtysh, Ili, Talas, Korgas. Although Kazakhstan reached some progress in addressing transboundary water issues to China, main interstate agreement for water allocation along Trans Boundary River has not been reached despite the progress for today Korgas is the first river on which agreement was reached on an equal share on water allocation. However, two countries still have unresolved cross-border water issues. Irtysh and Ili water resources remain not included on the table of negotiation. Apparently, China's fast growing population in the western part will extend the country's plans to irrigate more and more hectares. As evidence it will increase its demands for water in trans Boundary Rivers Irtysh and Ili will be the first in the list of rivers from which China will withdraw waters to develop prospective industrial zones in western regions. As a result Kazakhstan may face huge problems such as water deficit, mainly in East Kazakhstan. It will cause numerous problems to energy industries, agriculture, and metallurgy in this area. In fact, there is a threat of drought in East Kazakhstan in the coming future if the two countries do not immediately come to the strong negotiation of water use.

\section{Agreements reached between two countries on transboundary water use}

In September 2001, the Government of Kazakhstan and the People's Republic of China signed an agreement onthe use and protection oftransboundary water. In 2005, on the urgent notification of the parties about disasters on transboundary rivers, the Agreement between the Ministry of Agriculture of Kazakhstan and the Ministry of Water Resources of China was signed. The Kazakhstan-Chinese Commission was established not only for the use of transboundary rivers, but also for their protection. Therefore, drafts of agreements were approved:

(1) "Agreement between the Ministry of Environmental Conservation of Kazakhstan and the Ministry of Water

Resources of China about exchange of hydrological and hydrochemical information (data) from boundary gauging stations along the main transboundary rivers.

(2) Agreement the Ministry of Agriculture of Kazakhstan and the Ministry of Water Resources of China about the research cooperation development on transboundary rivers."

It took a long time to achieve equitable water allocation on the river Korgas which originates from Xinjiang Uighur Autonomous Region (XUAR) and flows to the east part of Almaty. Initially construction of hydrosystem on Korgas was proposed in 1992, but the agreement on the construction was signed only in November 2010. After long talks on transboundary water issues between the two nations, it was only in July 2013 whenKazakh Chinese joint hydrosystemthat allows fair and equitable water allocation of transboundary river was finally opened on Korgas River. Itmight seem that there is much progress in settling all cross-river issues between neighbors but unfortunately, it was only with regard to Korgas River thatan agreement of water regulation has been reached. In practice, number of transboundary water issues remains unresolved.

${ }^{1}$ A. Ryabtsev, The Report of the Republic of Kazakstan,CAWATER info, available at

http://www.cawater-info.net/5wwf/national report kazakhstan e.htm 


\section{Why does the use of Transboundary Rivers remain an unregulated sphere of relations between China and Kazakhstan?}

Although 21 years of successful diplomatic relations between two countries promise prosperity and stability, some unresolved problems still exist, especially in the area of trans-cross rivers regulations. There are several reasons.

First of all, China did not sign on any international legal instrument on transboundary rivers. "The United Nations Convention on the Law of the Non-Navigational Uses of International Watercourses (1997) clearly states: "Watercourse States shall participate in the use, development and protection of an international watercourse in an equitable and reasonable manner. Such participation includes both the right to use the watercourse and the duty to cooperate in the protection and development ..." (Article 5). It also says "Watercourse States shall, in utilizing an international watercourse in their territories, take all appropriate measures to prevent the causing of significant harm to other watercourse States". Where significant harm nevertheless is caused to another watercourse State, "...to discuss the question of compensation" (Article 7)". ${ }^{2}$ No signature of China on any of international legal instrument on transboundary water makes it difficult for Kazakhstan to have sufficient data on water use from Chinese part. Another problem which arises from here is that Kazakhstan cannot predict future projects or any ideas on transboundary waters of China and cannot make Chinese responsible for it.

Second, China insists on bilateral negotiations in resolving water issues. In turn, as the long-standing practice, bilateral negotiations with China did not give any meaningful results. China seeks to exclude from the trilateral negotiations with Russia and Kazakhstan (or Russia, Kazakhstan and Kyrgyzstan) on the issue of cross-border rivers. Given Russia's interest in solving the problems of shared water resources of the Irtysh, the Kazakh side has repeatedly expressed about the involvement of Russia and, if possible, of Kyrgyzstan as well, to the negotiations with China for the development of joint actions on the issue. However, the Chinese leadership has consistently held the impossibility of discussing the problem of transboundary rivers in the trilateral format. Russian experts also emphasize that China is reluctant to discuss the problems of the Irtysh River in a trilateral format, or under SCO.

Third, it is no secret that China announced a large-scale development of western China. China completed the construction of Black Irtysh-Karamay channel in Xinjiang Uighur Autonomous Region without Kazakhstan's consent. Water from the upper part of the Irtysh is used in the area of oil field near the city of Karamay. It is also planned to increase irrigation projects for the Ili River. In addition to this, there are also plans of significantly increasing the sown area of agricultural crops, mostly for grain and cotton in Xinjiang. "In Xinjiang, close to $96 \%$ of the water is used for agriculture. In the world, this is the highest share. This structure has already caused the destruction of the freshwater ecosystem. In some lower reaches of rivers, there is no longer any water. Some wetlands and lakes have degraded. Officials and farmers complained they were suffering from the most severe drought in 50 years and called for more water to be diverted from neighbouring Kazakhstan" ${ }^{3}$ wrote Jonathan Watts in his article about water crisis in Xinjiang. As you see Western China will need more and more water in the future. Projects developing the western regions of China include the construction of canals, reservoirs, dams, hydropower and other hydraulic structures. These plans are of concern to China, Russia and Kazakhstan Kazakhstan being in the worst position. According to estimates, the implementation of these projects will lead to environmental disaster in Eastern and Central Kazakhstan.

And finally, the last reason why Kazakhstan is in the unprivileged position is the internal problems within the state itself. At the talks, the Chinese side has always represented an experienced team of experts with expertise in water issues, as well as in law and diplomacy. In addition, the Chinese government has unlimited funds to the delegations which are going to the joint action within the Commission. On the other hand, in Kazakhstan, there has been an acute shortage of young skilled workers, including those on water management in the last two decades. It leaves room for broader discussions within the state.

\section{Consequences of water policies and water allocation principles of neighboring state}

The matter of increasing the water intake from the rivers Irtysh and Ili in China is an extremely difficult moment in the Kazakh-Chinese relations in the field of shared water resources. It should be noted that since 1994, Kazakhstan has been trying to resolve the problem of joint control over the use of water resources of the Irtysh and Ili. Irtysh River originates from the southern slopes of the Altai Mountains. It is the only one river of the Xinjiang Uighur Autonomous Region which drains into the ocean. Many analysts in Kazakhstan worry about the list of negative consequences that entails China's further expansion off the boundary. Here are some of negative consequences from the analysts' view:

\footnotetext{
2 K. Muratshina, The Irtysh River in the hydro policy of Russia, Kazakhstan and China, Russian International Affair Council, 2012, available at

3 J. Watts, Pay farmers to halt irrigation to ease water crisis, Chinese adviser urges, The Guardian, 2009, available at http://www.guardian.co.uk/environment/2009/may/18/water-china-farmers 
- Damage of the natural water balance and the balance of the nature in the area of Lake Balkhash and Zaysan (East Kazakhstan);

- An increase of natural concentration of harmful substances in the water, making it impossible for household and domestic use;

- Degradation of the environment;

- Deterioration of the epidemiological situation in these regions;

- $\quad$ Problems with the water supply to the coastal villages and towns;

- Pasture degradation;

- $\quad$ Reduction in crop yields. ${ }^{4}$

In my opinion, I can also add:

- $\quad$ the prospect of becoming a zone of ecological disaster of one of the most beautiful lakes in the country with clean, fresh water (Balkhash);

- declining fish stocks and consequently the elimination of livelihoods of coastal communities;

- $\quad$ the emergence of social tension in the surrounding regions as a result of unemployment of people in nearby towns. (Semipalatinsk, Ayaguz, Ust- Kamenogorsk, Zaysan, Pavlodar, etc.)

Thus, the planned large-scale sampling of transboundary rivers Ili and Irtysh will cause serious and far-reaching harmful consequences on national economy, particularly Eastern Kazakhstan. It has a domino effect on the economy of the Omsk region of Russia which in turn will have its most negative impact on the natural and ecological balance of the entire Central Asian region. In order to prevent catastrophic problems in the region, both sides need to immediately come to the negotiation about transboundary water resources.

\section{Conclusion}

Kazakhstan declared its concerns about proper allocation and protection of Ili and Irtysh rivers many times, but China leaves the question of rational use of transboundary rivers open. Here are some suggestions on how to solve boundary river problems between two countries. There is a need to emphasize the role of Shanghai Cooperation Organization (SCO) as the main organization in Central Asia.

(1) The establishment of the joint Kazakh-Chinese working commission for environmental impact assessments, as well as to monitor the situation on rivers with China, especially on the rivers Irtysh and Ili;

(2) Providing information access to the public of Kazakhstan from Chinese part. Show the results of environmental impact assessments and monitoring coverage of the working committee as well as the future projects going to be constructed on the transboundary rivers in the media;

(3) The establishment of joint ventures in Kazakhstan and China for the production of water-saving technologies;

(4) The signing of a trilateral (Kazakhstan, Russia, China) agreement on the use and protection of resources of the river Irtysh which is the main water resource in East Kazakhstan, as well as on the creation of a system of joint monitoring of both quantitative and qualitative indicators of treatment, the study of their status, trends, and rapid exchange of information with the inclusion in the agreement of the item on the commitments to drain the rivers Irtysh and Ili China is not below the level agreed between the countries;

(5) The conclusion of the International Agreement on the protection and use of waters of the Irtysh, which should be based on the Convention on the Protection and Use of Transboundary Watercourses of March 17, 1992, and the monitoring of implementation. Provisions of sanctions from the international law organizations are necessary in a case of refusal from the Chinese side. In this case, it is necessary to exploit the potential of the SCO, given the parties represented in the framework of the regional structure, the key objective of which are the joint provision and maintenance of peace, security and stability in the region, as well as the protection of the environment of the participating countries.

In my opinion members of SCO should accelerate the commissioning of the SCO Development Fund, where one of the activities will be aimed at resolving the situation of water use of transboundary rivers of the participating countries. It would be a great step to establish an SCO special working body that controls and monitors the use of transboundary river resources in the member states with the obligatory participation of the chairmen of the committees on water resources of the member countries. I would also suggest putting the problem of Irtysh and Ili rivers on the table of international problem. However, it has to be taken into account that the problem of using thetransboundary river resources in Kazakhstan and China can be solved only if there is a consolidation of stakeholders and availability of partnership dialogue. This is the foundation in the mechanisms of the SCO.

\footnotetext{
${ }^{4}$ A. Revsky, Faktorvody: EgoizmKitayagrozitKazahstanuekologicheskoikatastrofoi, (Water factors: Self- interests of China threatens ecological disaster of Kazakhstan), APN Kazakhstan, 2006, available in Russian language at http://www.apn.kz/publications/article5569.htm 
Till recently, the fundamentally important issues for Kazakhstan that are related to control over water quality in transboundary rivers and prevention of their pollution, as well as the consideration of the principle for water distribution along transboundary rivers were not perceived by the Chinese party properly. ${ }^{5}$ On the $6^{\text {th }}$ of April 2013, the president of Kazakhstan met with the leader of PRC, Xi Jinping. And as Tengrinews.kz reports, Kazakhstan and China will solve the problem of transboundary rivers. The sides discussed issues of strategic cooperation. In particular, they touched upon the allocation of cross-border rivers. Mr. Xi Jinping said that "China will never do anything to harm, damage to the Kazakh economy. This issue will be resolved by treaty, and we create a working group," - said NursultanNazarbayev. ${ }^{6}$ In general, I can conclude that there the seriousness of the possible consequences of unsustainable water use of transboundary waters between two countries is now understood. The leadership of both countries seems to have the political will to address this issue. Only time will tell how deep the understanding of the seriousness of the problem really is.

\section{References}

[1] A. Ryabtsev, The Report of the Republic http://www.cawater-info.net/5wwf/national_report_kazakhstan_e.htm

[2] K. Muratshina, The Irtysh River in the hydro policy of Russia, Kazakhstan and China, Russian International Affair Council, 2012. http://russiancouncil.ru/en/inner/?id_4=437

[3] J. Watts, Pay farmers to halt irrigation to ease water crisis, Chinese adviser urges, The Guardian, 2009. http://www.guardian.co.uk/environment/2009/may/18/water-china-farmers

[4] A. Revsky, Faktorvody: EgoizmKitayagrozitKazahstanuekologicheskoikatastrofoi, (Water factors: Self- interests of China threatens ecological disaster of Kazakhstan), APN Kazakhstan, 2006. http://www.apn.kz/publications/article5569.htm

[5] A. Ryabtsev, Threats to water security in the Republic of Kazakhstan in the transboundary context and possible ways to eliminate them, p.4. http://www.icwc-aral.uz/workshop_march08/pdf/ryabtsev_en.pdf

[6] D.Hegai, Kazakhstan i Kitaireshaiut problem transgranichnyhrek, (Kazakhstan and China resolves transboundary water problems), Tengri News, 2013. http://tengrinews.kz/kazakhstan_news/kazahstan-i-kitay-reshat-problemu-transgranichnyih-rek-231537/

\footnotetext{
5 A. Ryabtsev, Threats to water security in the Republic of Kazakhstan in the transboundary context and possible ways to eliminate them, p.4, available at http://www.icwc-aral.uz/workshop march08/pdf/ryabtsev en.pdf

${ }^{6}$ D.Hegai, Kazakhstan i Kitaireshaiut problem transgranichnyhrek, (Kazakhstan and China resolves transboundary water problems), Tengri News, 2013, available in Russian language at

http://tengrinews.kz/kazakhstan news/kazahstan-i-kitay-reshat-problemu-transgranichnyih-rek-231537/
} 